\title{
An Analysis of Circulating Betatrophin Levels in Relation with Type1 and Type2 Diabetes Mellitu Running Title: Betatrophin and Diabetes

\author{
Esma Altunoglu ${ }^{1 *}$, Fusun Erdenen ${ }^{1}$, Seda Aydın ${ }^{1}$, Atakan Koro ${ }^{2}$ and Hafize Uzun ${ }^{3}$ \\ ${ }^{1}$ Department of Internal Medicine Istanbul Training and Research Hospital, Turkey \\ ${ }^{2}$ Department of Biochemistry, Istanbul Training and Research Hospital, Turkey \\ ${ }^{3}$ Department of Biochemistry, Cerrahpasa Faculty of Medicine, Istanbul University Cerrahpasa, Turkey
}

\begin{abstract}
Background: Betatrophin is a newly identified liver-derived hormone that is associated with glucose homeostasis and lipid metabolism. Previous researches of betatrophin on glucose and lipid metabolism were mainly done under insulin resistant conditions. Only three studies from two centers investigated the association between betatrophin and type1 diabetes mellitus (T1DM). There is no consensus about the association of diabetes and betatrophin levels. Main purpose of this study was to investigate the relationship between betatrophin and various markers affecting glucose and lipid metabolisms in T1DM, type 2 diabetes mellitus (T2DM) and control subjects.
\end{abstract}

Methods: T1DM (n: 64), T2DM (n: 67) and control subject (n: 31) enrolled in this study. All subjects' physical examination, measurements of antropometric parameters and blood pressures were documented. Insulin, C-peptide, HbAlc, triglyceride, LDL-C, HDL-C, CRP, microalbuminuria, and betatrophin levels were measured in all groups.

Results: Serum betatrophin levels were significantly increased in patients with T1DM ( $p$ : 0.0001). Betatrophin was correlated with LDL-C in T1DM ( $r$ : 0.265, p: 0.034). No relationship between betatrophin and glucose metabolism (FBG, HbA1C) in T1DM was observed. Serum betatrophin levels were not increased in T2DM patients. Further more, we observed a significant positive correlation between betatrophin and FBG ( $r: 0.289, p: 0.019)$ and HbA1c ( $r: 0.372$, $\mathrm{p:}$ 0.002) in T2DM. As distinct from previous studies we did not find any relationships between betatrophin and insulin resistance in any groups.

Conclusions: Betatrophin is significantly higher in T1DM. Betatrophin levels correlated positively with markers of glycemic control in T2DM. Circulating betatrophin levels appeared to be the metabolic parameters of the T2DM rather than T1DM.

\section{Keywords}

Betatrophin, Type 1 diabetes mellitus, Type 2 diabetes mellitus, Glycemic control

\section{Introduction}

Progressive loss of mass and function of beta cells are important pathophysiological features of diabetes. There by the best therapy and potential cure for both T1DM and T2DM is to replace orregenerate the insulin-producing pancreatic beta cell. Restoration of the functional beta cell mass is therefore expected to be a key aim of diabetes therapy. In this context, researchers from Harvard Stem Cell Institute (HSBI) recently found a new hormone and named it betatrophin, which could increase the quantity of insulin producing betacells in mice [1]. Before discovery of betatrophin by $\mathrm{HSBI}$, different research teams have named this hormone differently according to its different functions: Including angiotensin amyloid 8(ANGPTL8), lipoprotein lipase
*Corresponding author: Esma Altunoglu, Department of Internal Medicine Istanbul Training and Research Hospital, Fatih, Istanbul, 34098, Turkey

Accepted: June 28, 2021

Published online: June 30, 2021

Citation: Altunoglu E, Erdenen F, Aydın S, et al. (2021) An Analysis of Circulating Betatrophin Levels in Relation with Type1 and Type 2 Diabetes Mellitu Running Title: Betatrophin and Diabetes. Ann Endocrinol Metab 4(1):61-67 
Citation: Altunoglu E, Erdenen F, Aydın S, et al. (2021) An Analysis of Circulating Betatrophin Levels in Relation with Type1 and Type2 Diabetes Mellitu Running Title: Betatrophin and Diabetes. Ann Endocrinol Metab 4(1):61-67

inhibition (lipasin), refeeding induced in fat and liver (RIFL), hepatocellular calcinoma-association gene (TD26) [2-5].

In humans, betatrophin is encoded by the C19 or F80 gene, secreted protein of 198 aminoacides [6]. Betatrophin is recently identified as a circulatory adipokine, mainly secreted from liver and adipose tissues. Liver-derived proteins known as hepatokines have ambivalend roles; they either decrease insulin resistance or improve metabolic variable of T2DM (eg: Fetuin-A, irisin, fibroblast growth factor 21). Betatrophin was initially proposed for its action on beta cell proliferation, although this has recently been questioned [7]. Even a previously reported positive effect of betatrophin on regeneration of pancreatic beta cells is now currently considered to be negative $[1,8]$. As fibrinogen-like domain (FNDC 5) is absent, betatrophin is recognized to be anatypical member of the ANGPTL protein family [9]. Betatrophin has a smilar gen structure to ANGPTL 3 . In animal models, in the lipid tissue irisin, which is a member of classical ANGPTL protein family, secretates betatrophin viaun copling protein 1(UCP1) [10].

Although it is now important to understand how betatrophin acts at systemic, cellular and molecular levels. So, most studies reported blood betatrophin levels to be high in patients with diabetes mellitus while some studies found no difference between DM and non-DM patients [11-13]. Furthermore, betatrophin was reported to be increased in serum of T1DM, suggesting that hepatic insulin resistance is not necessary for betatrophin release [14]. Also, betatrophin a nutritionally regulated factor and involved in the pathophysiology of lipid metabolism is an important regulator of plasma lipids. Some studies reported blood betatrophin levels to correlate with triglyceride levels, but others showed no correlation [15-18]. Hence, the impact of betatrophin in humans has not been clarified. Moreover, previous studies didnot focusif betatrophin was related with both C-peptide and insulin levels. Increased betatrophin levels may be an early and better predictor of beta cell reserves and metabolic parameters in diabetic patients. We hypothesized that betatrophin concentrations which are positively correlated with the markers of glycemic control and serum lipid levels, are different among T1DM and T2DM. The aim of this study is to investigate the relationship of betatrophin levels with C-peptide and insulin in three separete groups: T1DM, T2DM and control subjects. Explorations of potential correlations with glucose and lipid metabolism are also with in our goals.

\section{Methods}

\section{Subjects}

In the present study, the leakage difference between control and diabetic groups were found to be between $44 \%-72 \%$ via the power analysis conducted by $\mathrm{G}$ power 3.1 programs. Parametric distribution assumptions were considered, and minimum patient number was assumed to be 30. Our sample groups consisted of 67 previously diagnosed T2DM, 64 T1DM and 31 control individuals with comparable age, sex andbody mass index (BMI) satisfying the requirements of a power rating of 0.8 . The study protocol was approved by the Ethics Committee of Istanbul Education and Research Hospital (no: 796, date: 11.03.2016) and it conformed to the principles outlined in the Declaration of Helsinki in 1995 (as revised in Tokyo 2004). The written informed consents were obtained from all participants before the initiation of study.

Inclusion criteria: 1 . Diabetic patients with durations of diabetes at least $>3$ years and their medical records based on the ADA criteria (2016). 2. Control subjects, who were selected from the hospital staff, did not have a family history of diabetesand theiroral glucose tolerance test (OGTT) showed 2-hour BG < $180 \mathrm{mg} / \mathrm{dl}$. Following exclusion criteria were applied: 1. Patients with secondary diabetes or specific type of diabetes; 2 . Ketoacidosis, lactic acidosis, hyperglycemic hyperosmolar stateduring enrolment; 3 . Subjects with diabetic foot or inflammatory or infectious diseases; 4 . Acute myocardial or cerebral infarctionduring enrollment; 5 . Familial hyper cholesterolemia and samples with visible lipemic and hemolysis; 6 . Heart failure, severe impaired liver function or alcoholism; 7. Renal disease (diabetic nephropathy) (GFR< $60 \mathrm{ml} / \mathrm{min} / 1.73 \mathrm{~m}^{2}$ ), proliferative diabetic retinopathy; 8 . Pregnancy or lactation; 9. Impaired hematopoietic function and malignancy.

\section{Physical and anthropometric measurements}

Each subject underwent a complete physical examination by the same physician at the Internal Medicine Outpatient Clinic of our Hospital. Blood pleasure (BP) was measured with using an Omron HEM-907XL digitals phygmomanometer. An average of 2 BP reading with 5-10 minutes rest between each was obtained. Weight and height were measured with participants wearing light clothing and bare footed, using calibrated portable electronic weight scales and portable inflexible height measuring bars. BMI was calculated using the standard BMI formula: Body weight (in kilograms) divided by height (in meters squared). Waist circumference was measured twice of the nearest $0.1 \mathrm{~cm}$ with flexible tape measure at the level of minimum circumference which was usuallyat the level of the navel.

\section{Laboratory analysis}

All subjects had at least 12 hours of fasting before blood sampling for biochemical analysis. Fasting blood samples were collected in EDTA-containing, anticoagulant free tubes in the morning and centrifuged immediately $(3000 \mathrm{~g})$ for $10 \mathrm{~min}$ at $+4^{\circ} \mathrm{C}$, plasma and serum were separated in Eppendorf tubes and frozen immediately at $-80^{\circ} \mathrm{C}$ until analysis of betatrophin. Fasting blood glucose (FBG), urea, creatinine, triglyceride, total cholesterol (TC), high-density cholesterol (HDL-C), lowdensity cholesterol (LDL-C) and albumin were measured spectro photometrically using the Abbott Aeroset 2.0 (Abbot Diagnostic, USA). The analysis of C-reactive protein (CRP) was performed by nephelometric (IMAC-Beckman coulter, Germany). HbAlc \% was measured by the Premier Hb9210 (Trinity Biotech, Ireland) which uses the glycation specific binding of boronated affinity to detect all the glycated $\mathrm{Hb}$ species present. GFR was calculated using the MDRD formula [19]. Fasting insulin was measured by enzymatic immunoassay using direct chemiluminescent (BergmanCoulter, Inc.). The 
Citation: Altunoglu E, Erdenen F, Aydın S, et al. (2021) An Analysis of Circulating Betatrophin Levels in Relation with Type1 and Type2 Diabetes Mellitu Running Title: Betatrophin and Diabetes. Ann Endocrinol Metab 4(1):61-67

analysis of C-peptide was performed by two-side sandwich immunoassay using chemiluminescent (Siemens Healthcare Diagnostic, Germany). Insulin resistance was calculated using the HOMA-R formula: Fasting glucose $(\mathrm{mg} / \mathrm{dl}) \times$ fasting insulin $(\mathrm{mlU} / \mathrm{ml}) / 405$.

\section{Measurement of plasma betatrophin (ANGPTL8) levels}

Plasma betatrophin levels were measured by a commercially available enzyme-linked immunosorbent assay kit (Human (ANGPTL8) ELISA Kit, Sunred, Cat No: 201-125327). The coefficients of intra and inter-assay variation were $4.8 \%(n=20)$ and $6.1 \%(n=20)$ respectively.

\section{Statistical analysis}

In this study, statistical tests were conducted with NCSS (Number Cruncher Statistical System) 2007 Statistical Software (Utah, USA) program. While evaluating the results descriptive statistical methods (average, standard deviation) were utilized. In multiple-group comparisons unilateral variance analysis was used. Qualitive data was evaluated with chi-square test, while variants were compared with Pearson correlation test. To demonstrate the relationship between betatrophin and C-peptide the area under the ROC curve was calculated; sensitivity, specificity, positive predictive value (PPV), negative predictive value (NPV) and Likelihood Ratio (LR) were calculated. Results were evaluated with significance $\mathrm{p}<0.05$ and confidence bounds within $95 \%$. Mann Whitney $U$ test was used for pos hoc test of nonparametric variables, and Tukey Test was used for pos hoc test of parametric variables. Multinomial logistic regression analysis was used for significantly relevant parameters.

\section{Result}

The clinical characteristics of the three groups including T1DM, T2DM and control subjects are presented in (Table 1). There are no differences among three group sinage, gender, smoking / alcohol consumption. Waist circumference (WC), systolic blood pressure (SBP), and diastolic blood pressure (DBP) were significantly higher in T2DM than T1DM or control subjects ( $p: 0.004, p: 0.001, p: 0.008$ respectively). Yet, duration of diabetes with T1DM was significantly longer than T2DM (p: 0.0001).

The metabolic parameters of study groups are shown on (Table 2). Betatrophin values (cutoff: $116 \mathrm{ng} / \mathrm{l}$ according to ROC curve) were significantly higher in T1DM group than T2DM or control subjects $(322,73 \pm 266,05 \mathrm{ng} / \mathrm{l}$ vs. $144,84 \pm$ $124,5 \mathrm{ng} / \mathrm{l}$ vs. $106,19 \pm 59,07 \mathrm{ng} / \mathrm{l}$ ) respectively (p: 0.0001 ). As expected, C-peptide and insulin values were significantly lower in T1DM than T2DM or control groups ( $p: 0.0001, p$ : 0.0001 respectively). Glomerular filtration rate (GFR) was significantly less in T2DM than T1DM and control groups ( $p$ : 0.003 , p: 0.006 respectively). T1DM and T2DM were both micro albuminuria positive, but there wasno meaningful difference between T1DM and T2DM groups with regard tomicro albuminuria. There was no significant difference among three groups'triglyceride, HDL-C, albumin and CRP levels. Total cholesterol (TC) and LDL-C values were significantly higher in T2DM than T1DM1 and control groups (p: 0.036, p: 0.037 respectively).

As expected, fasting blood glucose and $\mathrm{HbAlc}$ values were significantly lower in control groups than diabetic groups (p: $0.0001, p: 0.0001$ respectively). (Table 3) demonstrates correlation between betatrophin and C-peptide with metabolic parameters among the study groups. Betatrophin levels are significantly correlated with FBG ( $p: 0.019)$ and HbA1c (p: 0.002) in T2DM not in T1DM. On the other hand, in T1DM betatrophin levels are correlated with LDL-C ( $r$ : $0.265, \mathrm{p}: 0.034)$, there are no correlations with either HDL-C or TG. According to binary logistic analysis results duration of diabetes, betatrophin, C-peptide, total cholesterol and insulin levels of patients had significant contribution to type of DM. Effects of duration of DM and betatrophin were positive, whereas effects of C-peptide, total cholesterol and insulin levels were negative.

The most effective factor was C-peptide, followed by insulin and duration of DM. There was no correlation between insulin resistance and betatrophin levels among the groups. Parameter estimates are shown on (Table 4). According to ROC curves, AUC, cut off levels of betatrophin, sensitivity, specificity, PPV, NPV and LP in control, T1DM, T2DM groups are shown on the (Table 5). The likelihood of having T1DM for patients who had betatrophin value $\geq 116 \mathrm{ng} / \mathrm{l}$ was 6.46 times more than patients who had betatrophin level $<116$ $\mathrm{ng} / \mathrm{l}$. The likelihood of having T2DM was 3.39 times more in patients who had betatrophin level $>116 \mathrm{ng} / \mathrm{l}$ compared with patients having betatrophin level $<116 \mathrm{ng} / \mathrm{l}$. Among diabetic patients, prediction capacity of betatrophin for T2DM was 2,51 times more than patients who had betatrophin level > $94 \mathrm{ng} / \mathrm{l}$. These results state that betatrophin cannot be used as a diagnostic marker for diabetes.

\section{Discussion}

We foundthat circulating betatrophin is elevated in Turkish T1DM patients, but not in T2DM and control groups. We were not able tofind any relationships between betatrophin and glycemic control such as FBG and HbAlc in T1DM. Betatrophin had a significant positive correlation with the duration of diabetes in T1DM. There was no correlation of insulin or C-peptide and insulin resistance between betatrophin in any of the groups. No correlation was found with microalbuminuria and GFR. Furthermore, we observed a relationship of betatrophin with FBG and HbAlc in T2DM patients. We are the third center that has found elevated betatrophin levels in patients with T1DM and betatrophin is correlated with the LDL-C levels. In accordance with our results, Espeset, et al. [14] showed that increased plasma betatrophin of the Sweden's T1DM patients wastwiceof the patients with normal glucose tolerance and the plasma contents did not correlate with C-peptideor anyother metabolic parameters. They also have shown that betatrophin levels were higher in older non-diabetic control subjects while T1DM patients did not show a similar trend. In our study there is no age difference among three subject groups. So, our population does not show age dependent betatrophin levels. In the early phases of the disease patients with T1DM 
Citation: Altunoglu E, Erdenen F, Aydın S, et al. (2021) An Analysis of Circulating Betatrophin Levels in Relation with Type1 and Type2 Diabetes Mellitu Running Title: Betatrophin and Diabetes. Ann Endocrinol Metab 4(1):61-67

Table 1: General characteristics of the study groups.

\begin{tabular}{|c|c|c|c|c|c|c|c|c|c|}
\hline & & \multicolumn{2}{|c|}{ Control Group n: $\mathbf{3 1}$} & \multicolumn{2}{|c|}{ Type 1 DM n: 64} & \multicolumn{2}{|c|}{ Type 2 DM n: 67} & p & $\begin{array}{l}\text { Significant within group } \\
\text { differences }\end{array}$ \\
\hline \multicolumn{2}{|c|}{ Age (years) } & \multicolumn{2}{|c|}{$56.84 \pm 7.66$} & \multicolumn{2}{|c|}{$56.25 \pm 9.33$} & \multicolumn{2}{|c|}{$59.78 \pm 8.42$} & $0.055^{\mathrm{a}}$ & N/A \\
\hline \multirow{2}{*}{ Gender } & Male & 10 & $32.3 \%$ & 26 & $40.6 \%$ & 24 & $35.8 \%$ & \multirow{2}{*}{$0.705^{c}$} & \multirow{2}{*}{ N/A } \\
\hline & Female & 21 & $67.7 \%$ & 38 & $59.4 \%$ & 43 & $64.2 \%$ & & \\
\hline \multicolumn{2}{|c|}{ Height (kg) } & \multicolumn{2}{|c|}{$162.45 \pm 10.47$} & \multicolumn{2}{|c|}{$163.69 \pm 8.78$} & \multicolumn{2}{|c|}{$162.03 \pm 9.3$} & $0.585^{a}$ & N/A \\
\hline \multicolumn{2}{|c|}{ Weight (cm) } & \multicolumn{2}{|c|}{$78.97 \pm 13.56$} & \multicolumn{2}{|c|}{$77.3 \pm 14.87$} & \multicolumn{2}{|c|}{$81.63 \pm 11.81$} & $0.182^{\mathrm{a}}$ & N/A \\
\hline \multicolumn{2}{|l|}{ BMI } & \multicolumn{2}{|c|}{$30.07 \pm 5.38$} & \multicolumn{2}{|c|}{$29.00 \pm 6.07$} & \multicolumn{2}{|c|}{$31.18 \pm 4.49$} & $0.067^{a}$ & N/A \\
\hline \multicolumn{2}{|c|}{ Smoking (+) } & 6 & $20.7 \%$ & 14 & $21.9 \%$ & 20 & $29.9 \%$ & $0.482^{b}$ & N/A \\
\hline \multicolumn{2}{|c|}{ Alcohol (+) } & 1 & $3.4 \%$ & 5 & $7.8 \%$ & 2 & $3.0 \%$ & $0.418^{c}$ & N/A \\
\hline \multicolumn{2}{|c|}{$\mathrm{WC}(\mathrm{cm})$} & \multicolumn{2}{|c|}{$94.23 \pm 11.11$} & \multicolumn{2}{|c|}{$91.67 \pm 9.74$} & \multicolumn{2}{|c|}{$97.76 \pm 10.66$} & $0.004^{a}$ & Type 2 DM >Type $1 \mathrm{DM}^{\mathrm{e}}$ \\
\hline \multicolumn{2}{|c|}{ SBP $(\mathrm{mmHg})$} & \multicolumn{2}{|c|}{$126.77 \pm 10.45$} & \multicolumn{2}{|c|}{$126.25 \pm 13.03$} & \multicolumn{2}{|c|}{$134.93 \pm 14.81$} & $0.000^{d}$ & $\begin{array}{l}\text { Type } 2 \mathrm{DM}>\text { Type } 1 \mathrm{DM}^{f} \\
\text { Type } 2 \mathrm{DM}>\text { Type } 1 \mathrm{DM}^{f}\end{array}$ \\
\hline \multicolumn{2}{|c|}{$\mathrm{DBP}(\mathrm{mmHg})$} & \multicolumn{2}{|c|}{$79.68 \pm 3.4$} & \multicolumn{2}{|c|}{$78.44 \pm 7.34$} & \multicolumn{2}{|c|}{$81.72 \pm 5.47$} & $0.001^{d}$ & $\begin{array}{l}\text { Type } 2 \mathrm{DM}>\text { Type } 1 \mathrm{DM}^{\dagger} \\
\text { Type } 2 \mathrm{DM}>\text { Type } 1 \mathrm{DM}^{\dagger}\end{array}$ \\
\hline \multicolumn{2}{|c|}{ Diabetes duration (years) } & & & \multicolumn{2}{|c|}{$21.34 \pm 8.87$} & 12.7 & & $0.000^{a}$ & N/A \\
\hline
\end{tabular}

a) One Way ANOVA Test; b) Chi-Square Test; c) Chi-Square Likelihood Ratio; d) Kruskal Wallis H test; e) Tukey Test; f) Mann Whitney U Test, N/A: Not Applicable, ${ }^{*} \mathrm{p}<0.05$.

Table 2: Metabolic parameters of the study groups.

\begin{tabular}{|c|c|c|c|c|c|}
\hline & Control n: 31 & Type 1 DM n: 64 & Type 2 DM n: 67 & p & Significant within group differences \\
\hline Betatrophin(ng/l) & $106.19 \pm 59.07$ & $322.73 \pm 366.05$ & $144.84 \pm 124.50$ & $0.000^{\mathrm{a}}$ & $\begin{array}{l}\text { Type } 1 \mathrm{DM}>\text { >Controle } \\
\text { Type } 1 \mathrm{DM}>\text { Type } 2 \mathrm{DM}^{\mathrm{e}}\end{array}$ \\
\hline C-peptide(ng/ml) & $1.16 \pm 0.69$ & $0.56 \pm 0.34$ & $1.34 \pm 0.78$ & $0.000^{\mathrm{a}}$ & $\begin{array}{l}\text { Type } 1 \mathrm{DM}<\text { Control }^{\mathrm{e}} \\
\text { Type } 2 \mathrm{DM}>\text { Type } 1 \mathrm{DM}^{\mathrm{e}}\end{array}$ \\
\hline GFR(ml/dak -1.73m2) & $115.30 \pm 25.31$ & $111.07 \pm 27.96$ & $91.33 \pm 41.66$ & $0.000^{\mathrm{a}}$ & $\begin{array}{l}\text { Type } 2 \mathrm{DM}<\text { Control }^{\mathrm{e}} \\
\text { Type } 2 \mathrm{DM}<\text { Type } 1 \mathrm{DM}^{\mathrm{e}}\end{array}$ \\
\hline $\begin{array}{l}\text { Microalbuminuria } \\
\text { (mg/g) }\end{array}$ & $38.69 \pm 115.05$ & $129.50 \pm 318.09$ & $139.55 \pm 298.86$ & $0.010^{\mathrm{a}}$ & 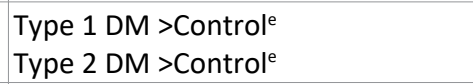 \\
\hline Total C)(mg/dl) & $202.55 \pm 43.74$ & $190.56 \pm 51.46$ & $211.27 \pm 44.90$ & $0.046^{b}$ & Type 2 DM >Type 1 DM $^{d}$ \\
\hline $\begin{array}{l}\text { Triglyceride } \\
\text { (mg/dl) }\end{array}$ & $135.77 \pm 76.98$ & $179.97 \pm 194.20$ & $196.45 \pm 133.29$ & $0.022^{\mathrm{a}}$ & Type 2 DM > Control ${ }^{\mathrm{e}}$ \\
\hline HDL-C(mg/dl) & $45.65 \pm 10.02$ & $45.95 \pm 15.17$ & $46.75 \pm 16.08$ & $0.895^{\mathrm{a}}$ & N/A \\
\hline LDL-C(mg/dl) & $122.81 \pm 33.57$ & $114.56 \pm 35.38$ & $131.46 \pm 39.80$ & $0.037^{b}$ & Type 2 DM >Type 1 DM $^{d}$ \\
\hline $\mathrm{FBG}(\mathrm{mg} / \mathrm{dl})$ & $84.58 \pm 12.91$ & $151.86 \pm 57.33$ & $162.17 \pm 43.76$ & $0.000^{\mathrm{a}}$ & 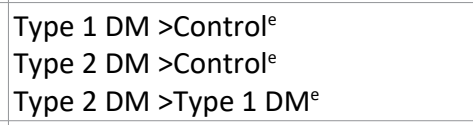 \\
\hline Insulin(qU/ml) & $7.02 \pm 1.19$ & $4.48 \pm 2.21$ & $7.22 \pm 3.04$ & $0.000^{\mathrm{a}}$ & $\begin{array}{l}\text { Type } 1 \mathrm{DM}<\text { Control }^{\mathrm{e}} \\
\text { Type } 2 \mathrm{DM}>\text { Type } 1 \mathrm{DM}^{\mathrm{e}}\end{array}$ \\
\hline Albumin(g/dl) & $4.28 \pm 0.26$ & $4.23 \pm 0.39$ & $4.24 \pm 0.33$ & $0.961^{\mathrm{a}}$ & N/A \\
\hline $\operatorname{CRP}(\mathrm{mg} / \mathrm{dl})$ & $0.67 \pm 0.50$ & $0.58 \pm 0.43$ & $0.81 \pm 1.49$ & $0.714^{\mathrm{a}}$ & N/A \\
\hline HbA1c(\%) & $6.38 \pm 1.09$ & $8.71 \pm 2.11$ & $8.49 \pm 2.02$ & $0.000^{b}$ & $\begin{array}{l}\text { Type } 2 \mathrm{DM}>\text { Control }^{\mathrm{d}} \\
{\text { Type } 1 \mathrm{DM}>\text { Control }^{\mathrm{d}}}^{\text {Ty }}\end{array}$ \\
\hline
\end{tabular}

Kruskal Wallis H Test, b. One Way ANOVA Test, d. Tukey Test, e. Mann Whitney U Test, N/A: Not Applicable

C-peptide: $0.8-3.85 \mathrm{ng} / \mathrm{ml}, \mathrm{GFR}>110 \mathrm{ml} / \mathrm{dk} / 1.73 \mathrm{~m}^{2}$, microalbuminuri: 30-300 mg/dl, T-cholesterol <200mg/dl, triglyceride $<150 \mathrm{mg} / \mathrm{dl}, \mathrm{LDL}-\mathrm{C}$ $<130 \mathrm{mg} / \mathrm{dl}, \mathrm{HDL}-\mathrm{C}:$ 40-60 mg/dl, FBG: 70-95 mg/dl, insulin: $1.923 \mathrm{qU} / \mathrm{ml}$, albumin: $3.5 \mathrm{~g} / \mathrm{dl}, \mathrm{CRP}: 0-5 \mathrm{mg} / \mathrm{dl}, \mathrm{HbA} 1 \mathrm{c}: 6.5 \%$

are lean, but as the years pass patients increase in BMI. As our study subjects had comparable BMI, we did not observe any relationship between betatrophin and BMI. Also, Yamada, et al. [20] focused on increased betatrophin levels in Japan's T1DM patients similar to our study. Like our results, Espes, et al. [21] found a positive correlation between betatrophin and $\mathrm{HbAlc}$ in T2DM patients.

As a result, three studies from two centers investigated the association between betatrophin and T1DM and all of them found a significant increased level of betatrophin in T1DM, like our study. Yi, et al. and a lot of other researchers showed increased levels of serum betatrophin in Chinese T2DM patients [22,23)]. Gomes-Ambrosi, et al. [13] showed that circulating betatrophin level was reduced in T2DM patients. There is heterogeneity observed among the studies. Different race, age and samples may be the reasons of this heterogeneity. In addition, diabetic patients assessed in the studies were taking hypoglycemic medications.

Since the effects of hypoglycemic agents on serum betatrophin levels are unclear, they might cause the potential confounding effects. However, several reports have indicated that circulating betatrophin levels were generally higher 
Citation: Altunoglu E, Erdenen F, Aydın S, et al. (2021) An Analysis of Circulating Betatrophin Levels in Relation with Type1 and Type2 Diabetes Mellitu Running Title: Betatrophin and Diabetes. Ann Endocrinol Metab 4(1):61-67

Table 3: Correlations between betatrophin and C-peptide among the study groups*.

\begin{tabular}{|c|c|c|c|c|c|c|c|}
\hline & \multirow[t]{2}{*}{ B } & \multirow[t]{2}{*}{ Std. Error } & \multirow[t]{2}{*}{ Wald } & \multirow[t]{2}{*}{ p } & \multirow[t]{2}{*}{$\operatorname{Exp}(B)$} & \multicolumn{2}{|c|}{$\begin{array}{l}\text { 95\% Confidence Interval } \\
\text { for } \operatorname{Exp}(B)\end{array}$} \\
\hline & & & & & & Lower Bound & Upper Bound \\
\hline Intercept & 8.271 & 2.910 & 8.079 & 0.004 & & & \\
\hline BMI & 0.123 & 0.069 & 3.171 & 0.075 & 0.884 & 0.772 & 1.012 \\
\hline Duration of diabetes (year) & 0.111 & 0.041 & 7.447 & 0.006 & 1.118 & 1.032 & 1.210 \\
\hline Betatrophin & 0.005 & 0.002 & 6.458 & 0.011 & 1.005 & 1.001 & 1.009 \\
\hline C-peptide & 3.510 & 0.882 & 15.850 & 0.000 & 0.030 & 0.005 & 0.168 \\
\hline Total cholesterol (mg/dl) & 0.021 & 0.008 & 6.987 & 0.008 & 0.980 & 0.965 & 0.995 \\
\hline Triglyceride (mg/dl) & 0.002 & 0.002 & 1.167 & 0.280 & 1.002 & 0.998 & 1.006 \\
\hline Insulin $(\mu \mathrm{U} / \mathrm{ml})$ & 0.400 & 0.149 & 7.212 & 0.007 & 0.670 & 0.500 & 0.898 \\
\hline HbA1c (\%) & 0.170 & 0.163 & 1.081 & 0.299 & 1.185 & 0.860 & 1.632 \\
\hline
\end{tabular}

Table 4: Parameter Estimates.

\begin{tabular}{|c|c|c|c|c|c|c|c|c|c|}
\hline \multirow{2}{*}{$\mathrm{dm}^{\mathrm{a}}$} & & \multirow{2}{*}{ B } & \multirow{2}{*}{ Std. Error } & \multirow{2}{*}{ Wald } & \multirow{2}{*}{ df } & \multirow{2}{*}{ Sig. } & \multirow{2}{*}{$\operatorname{Exp}(B)$} & \multicolumn{2}{|c|}{ 95\% ConfidencelntervalforExp(B) } \\
\hline & & & & & & & & LowerBound & UpperBound \\
\hline \multirow{9}{*}{1} & Intercept & 8.271 & 2.910 & 8.079 & 1 & .004 & & & \\
\hline & BMI & -.123 & .069 & 3.171 & 1 & .075 & .884 & .772 & 1.012 \\
\hline & Duration of DM & .111 & .041 & 7.447 & 1 & .006 & 1.118 & 1.032 & 1.210 \\
\hline & Betatrophin & .005 & .002 & 6.458 & 1 & .011 & 1.005 & 1.001 & 1.009 \\
\hline & C-peptide & -3.510 & .882 & 15.850 & 1 & .000 & .030 & .005 & .168 \\
\hline & T-Cholesterol & -.021 & .008 & 6.987 & 1 & .008 & .980 & .965 & .995 \\
\hline & TG & .002 & .002 & 1.167 & 1 & .280 & 1.002 & .998 & 1.006 \\
\hline & Insülin & -.400 & .149 & 7.212 & 1 & .007 & .670 & .500 & .898 \\
\hline & HBA1C & .170 & .163 & 1.081 & 1 & .299 & 1.185 & .860 & 1.632 \\
\hline
\end{tabular}

a. The reference category is: 2 .

Table 5: AUC, Cut off, Sensitivity, Specificity, PPV, NPV and LR of Betatrophin levels.

\begin{tabular}{|l|c|c|c|c|c|c|}
\hline Betatrophin(ng/l) & AUC & Cut off & Sensitivity & Specificity & PPV & NPV \\
\hline Control/T1DM & 0.740 & 116.00 & 62.50 & 90.32 & 93.0 & 53.8 \\
\hline Control/T2DM & 0.468 & 116.00 & 32.84 & 90.32 & 88.0 & 38.4 \\
\hline T1DM/T2DM & 0.710 & 94.00 & 62.69 & 75.00 & 72.4 & 65.8 \\
\hline
\end{tabular}

AUC: Area Under Curve; PPV: Positive Predictive Value; NPV: Negative Predictive Value

in metabolically disturbed state such as T1DM, T2DM, metabolic syndrome, and fatty liver disease Lee, et al.'s [24] study "a nested case-control study from a population-based prospective study", showed that patients with baseline betatrophin levels with significantly higher levels converted more to diabetes compared to non-converter group. So, betatrophin may be a possible biomarker for individuals at high risk for developing diabetes. Yi, et al.'s [25] study using ROC curve showed that circulating betatrophin concentration could be a diagnostic biomarker for T2DM, with optimal cutoff $501.23 \mathrm{pg} / \mathrm{ml}$. These two studies show that we observe increased levels of betatrophin in the early phases of the T2DM. Where as, in the present study ROC curve showed betatrophin cut-off as $116 \mathrm{ng}$./L. for diagnostic level in T2DM. Thus, due to our low PPV value we could not consider betatrophin as a diagnostic marker for T2DM.

It has been well established that betatrophin plays an important role of generalization of triglycerides. Studies on animals showed that over expression of ANGPTL8 for 8 days significantly increased plasma triglyceride levels but had no effect on glucose or insulin concentrations [26]. Alot of studies on humans showed that serum betatrophin levels have a positive correlation with triglyceride $[15,17,22,27]$. ANGPTL8/ betatrophin apparently induces triglycerides elevation through reducing triglycerides clearance by LPL inhibition [27-30]. As a result, betatrophin plays a significant role in the triglyceride metabolism. Fenzl, et al. [31] showed that betatrophin was associated with plasma atherogenic lipids in obesity and T2DM; but they did not observe any relationships with beta cell function and glucose homeostasis. Betatrophin also showed significant positive correlation with HDL-C in previous studies, $[25,28]$ yet it should be noted that these associations were not found in other reports. Also, Hassan, et al. [32] showed that betatrophin was not associated with triglyceride in T2DM. In the present study, we have not found any relationship between betatrophin and triglyceride in anyof the three groups. But we have found a relationship with betatrophin and LDL-Cin T1DM. So, atherogenic lipid profile was observed in our T1DM patient group, mainly because they were patients with longer duration of diabetes. 
Citation: Altunoglu E, Erdenen F, Aydın S, et al. (2021) An Analysis of Circulating Betatrophin Levels in Relation with Type1 and Type2 Diabetes Mellitu Running Title: Betatrophin and Diabetes. Ann Endocrinol Metab 4(1):61-67

Hyperglycemia and altered lipid profile are in association with diabetic nephropathy. Chen, et al. [33] found that serum betatrophin levels were positively correlated with microalbuminuria in T2DM patients. Also, they found serum betatrophin levels to be higher in patients with macroalbuminuria compared to normal albuminuria. One recent Japanese study in diabetic patients found a significant negative correlation between betatrophin andcreatinineclearance as well as GFR $[12,30]$. Incontrast, a recent German study investigating betatrophin levels in diabetic patients undergoing hemodialysis compared to diabetic individuals with sustained renal function, found significantly positive correlation between betatrophin and GFR [34].

They also found that patients on hemodialysis had significantly lower betatrophin levels compared with subjects having GFR $>50 \mathrm{ml} / \mathrm{min} / 1.73 \mathrm{~m}^{2}$. Espes, et al. [20] showed a positive correlation between plasma betatrophin levels and plasma creatinine in T2DM patients, which would suggest that betatrophin, may be excreted in the urine, though there was no correlation between betatrophin and calculated GFR. In the present study, we didnot find any correlation of betatrophin with microalbuminuria or calculated GFR in any of the three study groups. As we only included subjects with a calculated GFR $>60 \mathrm{ml} / \mathrm{min} / 1,73 \mathrm{~m}^{2}$, this may be the reason for lack of correlation between betatrophin with creatininein diabetic patients. Another reason may be that most of patients in our diabetic study groups have microvascular and macrovascular complications and they used ACE and AT2 drugs.

Our study has same limitations. First, we included previously diagnosed diabetic patients. They used antidiabetic medications such as metformin, thia zolidinediones that altered insulin resistance state in T2DM and exogenous insulin may also affect results. Second, postprandial levels of betatrophin could not be analyzed because we measured only fasting betatrophin levels. So fasting betatrophin levels cannot reflect betatrophin levels over time. Third, serum betatrophin levels were determined by ELISA without verification by western blotting. Lastly, liver tests like AST,ALT,ALF,GGT and upper abdominal ultrasound were not measured.

\section{Conclusion}

In this study, we found circulating betatrophin levels were higherin Turkish T1DM patients, though they were not correlated with metabolic parameters. Given the positive correlation of betatrophin levels with FBG and HbA1c in T2DM, we suggest that betatrophin measurement may be useful in the monitorization of diabetes regulation in T2DM. Contrary to common belief, we not found any relationship between betatrophin with insulin resistance. We not known that high betatrophin levels are observed in early phases of diabetes. If yes, close monitorization of patients with high betatrophin levels, hence strictregulation of their blood glucose can prevent and/or postpone microvascular complications. This is a significant finding in improving patient life expectancy. We recommend for researchers to perform prospective studies in larger groups evaluating betatrophin first marker or not of diabetic monitorization.

\section{Acknowledgements}

All costs of this study were funded by the education of Istanbul Education and Research Hospital.

\section{References}

1. Yi P, Park JS, Melton DA (2013) Betatrophin: A hormone that controls pancreatic beta cell proliferation. Cell 153: 747-758.

2. Yue S, Wu J, Zhang J, et al. (2016) The relationship between betatrophin levels in blood and T2DM: A systematic review and meta-analysis. Dis Markers 2016: 9391837.

3. Quagliarini F, Wang Y, Kozlitina J, et al. (2012) Atypical angiopoietin-like protein that regulates ANGPTL3. Proc Natl Acad Sci USA 109: 19751-19756.

4. Zhang R (2012) Lipasin, a novel nutritionally-regulated factor that regulates serum triglyceride levels. Biochem Biophys Res Commun 424: 786-792.

5. Ren G, Kim JY, Smas CM (2012) Identification of RIFL, a novel adipocyte-enriched insulin target gene with a role in lipid metabolism. Am J Physiol Endocrinol Metab 303: E334-E351.

6. Jin Zhou Zhu, Chao Hui Yu, You Ming Li (2014) Betatrophin provides a new insight into diabetes treatment and lipid metabolism. Biomed Rep 2: 447-451.

7. Alison Iroz, Jean Piere Couty, Catherine Postic (2015) Hepatokines: Unlocking the multi-organ network in metabolic diseases. Diabetologia 58: 1699-1703.

8. Yi P, Park JS, Melton DA (2017) Retraction Notice to: Betatrophin: A hormone that controls pancreatic beta cell proliferation. Cell 168: 326.

9. Niki H, KishimotoY, Saita E, et al. (2019) Plasma betatrphin levels and carotid atherosclerosis. Dis Markers 2019: 4214650.

10. Fabian Sanchis Gomar, Carme Perez Quilis (2014) The p38-PGC1 $\alpha$-irisin-betatrophin axis. Adipocyte 3: 67-68.

11. Wang YY, Zhang D, Jiang ZR, et al. (2015) The relationship between serum betatrophin levels of newly diagnosed type 2 diabetes patients and insulin resistance. China Modern Doctor 53: 4-6.

12. Hu H, Sun $W$, Yu S, et al. (2014) Increased circulating levels of betatrophin in newly diagnosed type 2 diabetic patients. Diabetes Care 37: 2718-2722.

13. Gomez Ambrosi J, Pascual E, Catalan V, et al. (2014) Circulating betatrophin concentrations are decreased in human obesity and type 2 diabetes. J Clin Endocrinol Metab 99: E2004-E2009.

14. Espes D, Lau J, Carlsson PO (2014) Increased circulating levels of betatrophin in individuals with long-standing type1 diabetes. Diabetologia 57: 50-53.

15. Jing Zheng, Juan Liu, Beverly Hong S, et al. (2020) Circulating betatrophin/ANGPTL8 levels correlate with body fat distribution in individuals with normal glucose tolarence but not those with glucose disorders. BMC Endocrine Disorders 20: 51.

16. Fenzl A, Itariu BK, Kosi L, et al. (2014) Circulating betatrophin correlates with atherogenic lipid profiles but not with glucose and insulin levels in insulin-resistant individuals. Diabetologia 57: 1204-1208.

17. Gusarova V, Alexa DA, Na E, et al. (2014) ANGPTL8/Betatrophin does not pancreatic beta cell expansion. Cell 159: 691-696.

18. Qu Q, Zhao D, Zhang F, et al. (2017) Serum betatrophin levels are increased and associated with insulin resistance in patients with polycystic ovary syndrome. J Int Med Res 45: 193-202. 
19. https://www.mdcalc.com/mdrd-gfr-equation

20. Yamada H, Saito T, Aoki A, et al. (2015) Circulating betatrophin is elevated in patients with type1 and type2 diabetes. Endocr J 62: 417-421.

21. Espes D, Martinell M, Carlsson P (2014) Increased circulating betatrophin concentrations in patients with type2 diabetes. International Journal of Endocrinology 6.

22. Gao T, Jin K, Chen $P$ et al. (2015) Circulating betatrophin correlates with triglycerides and postprandial glucose among different glucose tolerance statuses a case-control study. PloS One 10: e0133640.

23. Wang L, Song J, Wang C, et al. (2016) Circulating levels of betatrophin and irisin are not associated with pancreatic beta cell function in previously diagnosed type 2 diabetes mellitus patients. Journal of Diabetes Research 8.

24. Lee SH, Rhee M, Kwan HS, et al. (2018) Serum betatrophin concentrations and the risk of incident diabetes: A nested casecontrol study from chungju metabolic disease cohort. Diabetes Metab J 421: 53-62.

25. Yi M, Chen RP, Yang R, et al. (2015) Betatrophin acts as a diagnostic biomarkers in type 2 diabetes mellitus and is negatively associated with HDL-Cholesterol. Int J Endocrinol 2015: 579157.

26. Wang Y, Quagliarini F, Gusurova V, et al. (2013) Mice lacking ANGPTL8 (betatrophin) manifest disrupted triglyceride metabolism without impaired glucose homeostasis. Proc Natl Acad Sci USA 110: 16109-16114.
27. Liu D, Qu H, Wang H, et al. (2016) Relationship between serum betatrophin levels and the firsyt-phase of glucose-stimulated insulin secretion. Obesity Research Clinical Practice 12: 9-15.

28. Gomez Ambrosi J, Pascual Corrales E, Catalan V, et al. (2016) Altered concentrations in dyslipidemia evidence a role for ANGPTL8/betatrophin in lipid metabolism in humans. J Clin Endocrinol Metab 101: 3803-3811.

29. Takebayashi K, Hara K, Terasawa T, et al. (2017) Serum betatrophin levels and clinical features in patients whit poorly controlled type 2 diabetes. J Clin Med Res 9: 782-787.

30. Abu Farha M, Al Khairi I, Cherian P, et al. (2016) Increased ANGPRL3, 4 andANGPTL8/ betatrophin expression levels in obesity and T2DM. Lipids Health Dis 15: 181.

31. Maurer L, Schwarz F, Fischer Rosinsky, et al. (2017) Renal function is independently associated with circulating betatrophin. PLoS One 12: e0173197.

32. Hassan AB, Sali SF, Hassan Iletal. (2019) Circulating betatrophin in relation to metabolic, inflammatory parameters, and oxidative stress in patients with type 2 diabetes. Diabetes Metab Syndr 13: 458-463.

33. Chen C, Susanto H, Chuang W, et al. (2016) Higher serum betatrophin level in type 2 diabetes subjects is associated with urinary albumin excretion and renal function. Cardiovasc Diabetol 15: 3.

34. Ebert T, Kralisch S, Hoffmann A, et al. (2014) Circulating angiopoietin-like protein 8 is independently associated with fasting plasma glucose and type2 diabetes mellitus. J Clin Endocrinol Metab 99: E2510-E2517. 